CZASOPISMO INŻYNIERII LA¿OWEJ, ŚRODOWISKA I ARCHITEKTURY JOURNAL OF CIVIL ENGINEERING, ENVIRONMENT AND ARCHITECTURE

JCEEA, t. XXXIV, z. 64 (2/I/17), kwiecien-czerwiec 2017, s. 107-118, DOI:10.7862/rb.2017.56

\author{
Marian KLASZTORNY ${ }^{1}$ \\ Karol ZIELONKA ${ }^{2}$ \\ Daniel B. NYCZ ${ }^{3}$ \\ Pawel POSUNIAK ${ }^{4}$
}

\title{
EXPERIMENTAL VERIFICATION OF SIMULATION OF TB32 CRASH TEST FOR SP-05/2 ROAD SAFETY BARRIER ON HORIZONTAL CONCAVE ARC
}

\begin{abstract}
The study concerns a selected road safety barrier consisting of a B-type guiderail, Sigma-100 posts with $2.00 \mathrm{~m}$ spacing, and supporting elements of a trapezoid cross section, located between the posts and the guiderail. The barrier is formed on a horizontal concave arc having a radius of $150 \mathrm{~m}$. The full-scale experimental TB32 crash test was carried out for a vehicle impacting at the angle of $20^{\circ}$, on the testing grounds of the Automotive Industry Institute, Warsaw, Poland. The numerical modelling and simulation methodology of a barrier - vehicle system, recently developed by the authors is applied. Simulation of the above test was performed using LS-Dyna v.971 finite element code, while maintaining the conditions of the experimental test. All the functionality parameters for the barrier are studied, among others, ASI, THIV, working width, vehicle motion trajectory in the exit box. The results of the simulation tests were compared with those of the full-scale experimental test. The experimental verification of the numerical modelling and simulation of the selected crash test is rated positively. It was proven, both numerically and experimentally, that the TB32 crash test does not meet the condition imposed on the vehicle motion trajectory in the exit box.
\end{abstract}

Keywords: road safety barrier on horizontal concave arc, simulation crash test, experimental crash test, experimental verification of modelling and simulation

\section{Introduction}

According to standards $[1,2]$, crash tests certifying road safety barriers are performed experimentally on a straight section of the barrier. The approval crite-

${ }^{1}$ Corresponding author / autor do korespondencji: Marian Klasztorny, Military University of Technology, Faculty of Mechanical Engineering, Department of Mechanics and Applied Computer Science, 2 gen. S. Kaliskiego Street, PL-00908 Warsaw, Poland; phone: +48 605953 533; m.klasztorny@ gmail.com

2 Karol Zielonka, Automotive Industry Institute, 55 Jagiellonska Street, PL-03301 Warsaw, Poland; phone: +48 227777 015; k.zielonka@ pimot.eu

3 Daniel B. Nycz, Jan Grodek State Vocational Academy, Institute of Technology, 6 Reymonta Street, PL-38500 Sanok, Poland; phone: +48 698615 128; daniel.nycz@interia.pl

4 Pawel Posuniak, Automotive Industry Institute, 55 Jagiellonska Street, PL-03301 Warsaw, Poland; phone: +48 227777 015; p.posuniak@pimot.eu 
ria for a crash test include the following functional parameters of the barrier: ASI, THIV, working width, vehicle motion trajectory in the exit box, penetration of the vehicle into the barrier and vice versa, continuity of the guide rail during the collision. After performing a crash test, it should also be confirmed that the length of the test section of the barrier is sufficient to demonstrate the full operation of the system. Standard [3] introduces the possibility of certification by the simulation of road safety barriers slightly modified in reference to the so-called parent barrier (certified experimentally). It is therefore reasonable to develop numerical modelling and simulations of road crash tests.

The study concerns the full-scale experimental verification of the numerical modelling and simulation of the TB32 crash test for the selected road safety barrier on a horizontal concave arc. The literature review and methodology for the numerical modelling and simulation of crash tests, developed by part of the team of authors, was published in Refs. [4, 5]. This methodology is presented in Section 3 in a shortened form.

\section{Functionality criteria of road safety barriers}

Standard [1] defines the criteria for crash tests and the test methods to which road restraint systems should be subjected. Standard [2] describes action classes in reference to protective barriers via determining their functional characteristics, such as the restraint level, the working width, the collision intensity level. Standards $[1,2]$ do not include road bends.

Restraint levels are determined from crash tests including small (T1, T2, T3), normal (N1, N2), increased (H1, H2, H3), very high (H4a, H4b) levels. In the case of restraint level N2, the approval of TB11 and TB32 crash tests is required. The TB32 crash test conditions are as follows: impact velocity $110 \mathrm{~km} / \mathrm{h}$, collision angle $20^{\circ}$, total car mass $1500 \mathrm{~kg}$.

The collision intensity level reflects the impact of the collision on the vehicle's occupants, measured by the acceleration severity index, ASI, and the theoretical head impact velocity, THIV. The A level corresponds to ASI $\leq 1.0$, THIV $\leq 33 \mathrm{~km} / \mathrm{h}$. Parameter ASI specifies the size of the motion onerousness during the collision with the restraint system, for a human located in the vicinity of the vehicle centre-of-gravity. Acceleration severity index $\operatorname{ASI}(t)$ is calculated from the formula [1]

$$
\operatorname{ASI}(t)=\sqrt{\left(\frac{\bar{a}_{x}(t)}{\hat{a}_{x}}\right)^{2}+\left(\frac{\bar{a}_{y}(t)}{\hat{a}_{y}}\right)^{2}+\left(\frac{\bar{a}_{z}(t)}{\hat{a}_{z}}\right)^{2}}, \quad A S I=\max _{t}[\operatorname{ASI}(t)]
$$

where

$$
\bar{a}_{j}(t)=\frac{1}{\delta} \int_{t}^{t+\delta} a_{j}(t) d t, \quad j=x, y, z
$$


and: $x, y, z$ - longitudinal, lateral and vertical directions in the vehicle, respectively, $t$ - time variable, $a_{x}(t), a_{y}(t), a_{z}(t) \mathrm{a}_{\mathrm{x}}(\mathrm{t}), \mathrm{a}_{\mathrm{y}}(\mathrm{t}), \mathrm{a}_{\mathrm{z}}(\mathrm{t})-$ acceleration components related to the car centre-of-gravity, $\hat{a}_{x}=12 g, \hat{a}_{y}=9 g, \hat{a}_{z}=10 g$ - limits of acceleration components in $x, \quad y, z$-directions, $\bar{a}_{x}(t), \bar{a}_{y}(t), \bar{a}_{z}(t)$ $\overline{\mathrm{a}}_{\mathrm{x}}(\mathrm{t}), \overline{\mathrm{a}}_{\mathrm{y}}(\mathrm{t}), \overline{\mathrm{a}}_{\mathrm{z}}(\mathrm{t})$ - acceleration components related to the car centre-of-gravity, passed through a Butterworth four-pole no-phase digital filter, of lowbandwidth, of the limit frequency of $13 \mathrm{~Hz}$ (acceleration component values averaged over a moving time interval $\delta=50 \mathrm{~ms}), g=9.81 \mathrm{~m} / \mathrm{s}^{2}$ - gravity acceleration.

The theoretical head impact velocity, THIV, is used to evaluate the collision intensity, in relation to persons in the vehicle, during the car collision with the restraint system. It is assumed that a person inside the vehicle is an object (theoretical head) moving freely in such a way that during the turning of the vehicle (impact into restraint system), the head moves further in a straight line and irrespective of the vehicle, until the impact into an inside surface (walls of theoretical cabin). The collision speed of the theoretical head with the moving theoretical cabin is the THIV parameter. The calculation algorithm for parameter THIV takes into account the vehicle velocity components corresponding to the motion of the car in the $x y$-horizontal plane [6].

Working width $\mathrm{W}$ is the distance between the side face of the barrier from the traffic side before the collision and the maximum dynamic lateral position of any greater part of the barrier. The working width is a measure of barrier deformation. Standard [2] stands 8 levels of working width; level W4 corresponds to distance $\mathrm{W} \leq 1.3 \mathrm{~m}$.

The VCDI parameter is a deformation index of the vehicle compartment. The VCDI parameter record includes both the location and extent of damage to the car cab, in the form of XYabcdefg where XY - place of deformation (capital symbols), abcdefg - seven indices defining percent reduction in the seven characteristic interior dimensions of car cabin [2].

The car, after collision with the barrier and shifting in contact with the barrier, should bounce from the barrier so that the wheel trace does not exceed the front line of the exit box, which is located at a distance of $\mathrm{A}=2.2 \mathrm{~m}+$ the car width $+16 \%$ of car length [2]. For Dodge Neon car this distance is $A=4.53 \mathrm{~m}$. The exit box is $\mathrm{B}=10 \mathrm{~m}$ long, starting from the exit point of last wheel beyond the barrier face original line. Locking the vehicle in the barrier or skidding is permitted. The vehicle cannot roll over during and after the impact.

\section{Shortened description of methodology of numerical modelling and simulation of crash tests of road safety barriers}

The TB32 crash test was simulated using the non-linear explicit LS-Dyna FE code. The Dodge Neon car numerical model taken from the the public library 
developed by the National Crash Analysis Center, USA [7] and properly corrected, was applied. The vehicle numerical model includes more than 330 material models assigned to particular parts of car and consists of 279,700 finite elements. All the functionality parameters of the tested barrier, required by standards [1,2], were determined. The following software was used:

- preprocessing: Catia v5r19 ${ }^{\circledR}$ (Part Design $^{\circledR}$, Generative Shape Design ${ }^{\circledR}$, Assembly Design $\left.{ }^{\circledR}\right)$, HyperWorks $11.0^{\circledR}$ (HyperMesh $^{\circledR}$, HyperMorph $\left.{ }^{\circledR}\right)$, LSPrePost $4.2^{\circledR}$;

- processing: LS-Dyna v. $971^{\circledR}$;

- postprocessing: HyperWorks $11.0^{\circledR} \quad$ HyperView $^{\circledR}, \quad$ HyperGraph $\left.^{\circledR}\right)$, LS-PrePost $4.2^{\circledR}$, Excel $^{\circledR}$.

The numerical modelling and simulation was performed using the methodology as described in Refs. $[4,5]$ and LS-Dyna v.971 FE code. The main items of this methodology are described in Table 1 in a concise form. Original terms, symbols and units, used in the Keyword User's Manual [8] of the LS-Dyna FE code, are applied.

\section{Description of barrier SP-05/2 and experimental crash test technology}

A SP-05/2 ${ }^{\circledR}$ barrier [9] of the N2-W4-A category [2], made of hot-dip galvanized S235JR steel, is produced by Stalprodukt JSC Co., Bochnia, Poland.

Table 1. Parameters/options of modelling and simulation of crash tests of road safety barriers

Tabela 1. Parametry/opcje modelowania i symulacji testów zderzeniowych barier ochronnych

\begin{tabular}{|l|l|}
\hline \multicolumn{1}{|c|}{ Item } & \multicolumn{1}{c|}{ Parameters / options } \\
\hline $\begin{array}{l}\text { road safety barrier } \\
\text { shell steel parts } \\
\text { meshing }\end{array}$ & $\begin{array}{l}\text { 4-node shell finite elements of QUAD4 topology; } \\
\text { Belytsko-Tsai formulation with 1 in-plane integration point and 5 integra- } \\
\text { tion points through thickness (ELFORM_2 formulation) }\end{array}$ \\
\hline $\begin{array}{l}\text { road safety barrier } \\
\text { shell steel parts ma- } \\
\text { terial model }\end{array}$ & $\begin{array}{l}\text { *MAT_PIECEWISE_LINEAR_PLASTICITY (*MAT_24) elastic-plastic } \\
\text { model with isotropic hardening; } \\
\text { material constants taken from manufacturer's certification excluding FAIL } \\
\text { parameter (numerical parameter determined on basis of calibration tests } \\
\text { sensitive to meshing - plastic strain to failure and finite element erosion) }\end{array}$ \\
\hline $\begin{array}{l}\text { 6-screw joints of } \\
\text { guiderail segments }\end{array}$ & $\begin{array}{l}\text { discrete beam elements with 6 DOFs, reflected by 6 stiffness characteris- } \\
\text { tics (ELFORM_6 formulation); } \\
\text { *NONLINEAR_PLASTIC_DISCRETE_BEAM (*MAT_068) nonlinear } \\
\text { elastoplastic and linear viscous model; } \\
\text { parameters and stiffness characteristics determined by comparison of 3D } \\
\text { and 2D tension test modelling of guiderail joint section; } \\
\text { 3D modelling: } \\
\text { 8-node solid elements of HEX8 topology } \\
\text { constant stress solid element (ELFORM_1 formulation) } \\
\text { Flanagan-Belytschko stiffness form of hourglass control }\end{array}$ \\
\hline
\end{tabular}


Table 1 (cont.). Parameters/options of modelling and simulation of crash tests of road safety barriers

Tabela 1 (cd.). Parametry/opcje modelowania i symulacji testów zderzeniowych barier ochronnych

\begin{tabular}{|c|c|}
\hline Item & Parameters / options \\
\hline $\begin{array}{l}\text { guiderail-post bolt } \\
\text { joints }\end{array}$ & $\begin{array}{l}\text { *CONSTRAINED_GENERALIZED_WELD_SPOT kinematic con- } \\
\text { straints; } \\
\text { load capacities taken from bolt characteristics }\end{array}$ \\
\hline bolt preload & $\begin{array}{l}\text { dynamic relaxation procedure; } \\
\text { *INITIAL_STRESS_SECTION option; } \\
\text { approach used in 3D modelling only }\end{array}$ \\
\hline $\begin{array}{l}\text { asphalt/concrete } \\
\text { pavement surface; } \\
\text { roadside surface }\end{array}$ & rigid horizontal plane \\
\hline $\begin{array}{l}\text { road side soil mesh- } \\
\text { ing }\end{array}$ & $\begin{array}{l}\text { posts embedded in soil cylinders; } \\
\text { 3D finite elements of HEX8 and PENTA6 topology; } \\
\text { 8-node solid element, trilinear shape functions, } 1 \text { integration point } \\
\text { (ELFORM_1 formulation) }\end{array}$ \\
\hline $\begin{array}{l}\text { road side soil mate- } \\
\text { rial model }\end{array}$ & $\begin{array}{l}\text { *MAT_SOIL_AND_FOAM }(* \text { MAT_005) model; } \\
\text { material constants taken from NCAC library [7]; } \\
\text { soil cylinders coated with artificial shell with properties of } \\
\text { *MAT_NULL (*MAT_009) material; } \\
\text { no contact with roadside surface }\end{array}$ \\
\hline vibration damping & $\begin{array}{l}\text { *DAMPING_PART_STIFFNESS damping model; } \\
\text { damping ratios: } 0.03 \text { - road safety barrier shell steel parts, } 0.10 \text { - road } \\
\text { side soil }\end{array}$ \\
\hline car model & $\begin{array}{ll}\text { Dodge Neon car numerical model taken from NCAC public library [7]; } \\
\text { corrections to adapt car model to oblique crash tests: } \\
\checkmark & \text { changing tire model from *AIRBAG model into } \\
& \text { *AIRBAG_SIMPLE_PRESSURE_VOLUME model } \\
\checkmark & \text { declaration of tire pressure equal to 2.3 bar } \\
\checkmark & \text { correction of suspension (application of *MAT_66 material model } \\
& \text { and BEAM elements in ELFORM_6 formulation, stiffness and } \\
& \text { damping suspension adjustment, adding preload in dynamic relaxa- } \\
& \text { tion process) } \\
\checkmark & \text { dynamic relaxation (influence of gravity load) before starting vehi- } \\
& \text { cle collision with barrier } \\
\checkmark & \text { declaration of vehicle linear velocity and wheel angular velocity at } \\
& \text { start time point } \\
\checkmark & \text { adjustment of wheel alignment and wheel rotation axis } \\
\checkmark & \text { correction of contact options } \\
\checkmark & \text { correction of control cards } \\
\checkmark & \text { hourglass control (elimination of non-physical forms of vibration) } \\
\checkmark & \text { placing *ELEMENT_SEATBELT_ACCELEROMETER at car } \\
& \text { centre of gravity on rigid solid element connected to chassis by } \\
\checkmark & \text { means of *CONSTRAINED_EXTRA_NODES bonds } \\
& \text { correction of bond stiffness }\end{array}$ \\
\hline contact & $\begin{array}{l}\text { *CONTACT_AUTOMATIC_SINGLE_SURFACE model between } \\
\text { potential contact pairs; } \\
\text { additionally, *CONTACT_INTERIOR for roadside soil and foam }\end{array}$ \\
\hline
\end{tabular}


Table 1 (cont.). Parameters/options of modelling and simulation of crash tests of road safety barriers

Tabela 1 (cd.). Parametry/opcje modelowania i symulacji testów zderzeniowych barier ochronnych

\begin{tabular}{|l|l|}
\hline \multicolumn{1}{|c|}{ Item } & \multicolumn{1}{c|}{ Parameters / options } \\
\hline friction & $\begin{array}{l}\text { Coulomb kinematic friction; } \\
\text { experimental identification based on standards; } \\
\text { friction coefficients: steel - steel pairs: 0.25, steel - soil pairs: 0.30, dry } \\
\text { asphalt/concrete - tire pairs: 0.90, dry roadside - tire pairs: 0.68 }\end{array}$ \\
\hline Hourglass control & global stiffness procedure in Flanagan-Belytshko formulation \\
\hline displacements & large \\
\hline strains & large \\
\hline $\begin{array}{l}\text { numerical integra- } \\
\text { tion }\end{array}$ & $\begin{array}{l}\text { explicit; } \\
\text { finite difference method; } \\
\text { time step assumed based on Courant-Friedrichs-Levy criterion }\end{array}$ \\
\hline
\end{tabular}

The connectors use M16 bolt sets of a 4.6 strength class. The main structural components of the barrier are: a B-type guide rail consisting of segments of an overall length of $4.30 \mathrm{~m}$ and a $4.00 \mathrm{~m}$ effective length, Sigma-100 posts of a length of $1.90 \mathrm{~m}$ at intervals of $2.00 \mathrm{~m}$, supporting elements of a trapezoidal cross section and A-type rectangular pads [9]. The TB11 and TB32 crash tests results announced by the barrier producer are as follows: $\mathrm{ASI}=0.8, \mathrm{~W}=1.10 \mathrm{~m}$, $\mathrm{THIV}=23 \mathrm{~km} / \mathrm{h}, \mathrm{VCDI}=\mathrm{RF} 0001000$ (the right-front place of deformation, the fourth dimension shortened by no more than $10 \%$, the remaining characteristic dimensions shortened by no more than 3\%) [4].

Full-scale experimental crash tests were carried out on the testing grounds at the Automotive Industry Institute, Warsaw, Poland, designed to carry out crash tests on all restraint levels of a protection system. The testing grounds consist of two main parts:

- a drive track $3.2 \mathrm{~m}$ wide and $200 \mathrm{~m}$ long, equipped with a drive rail, driving ropes, a drive trolley and a drive motor, used to accelerate the vehicle

- a crash square of a $1300 \mathrm{~m}^{2}$ area (length $55 \mathrm{~m}$, width $25 \mathrm{~m}$ ).

The superstructure of the drive track and crash square is made of reinforced concrete. The load capacity of the track allows carrying out tests using vehicles weighing up to $40000 \mathrm{~kg}$. In the channel located in the track axis, the drive rail is installed, which is a guide for the drive trolley with roller bearings and steel wire ropes. The second trolley acts as a brake for the drive trolley and as a retarder for the drive rope.

In the crash test, the recording equipment met the requirements specified in standard [1]. The video recording uses three cameras for fast photos (min. 500 frames per second). The cameras were placed in front of and behind the barrier arc. The third camera was placed on an arm at a height of $24 \mathrm{~m}$ to record the respective crash site (top view). The impact speed of the car was measured using a laser device. To ensure safety, concrete barriers and an RC emergency braking 
system for the test vehicle were installed. The following measurement equipment was used:

- acceleration sensors -Measurement Specialties model $64 \mathrm{C}^{\circledR}$, mounted in the centre of gravity of the vehicle, to measure the acceleration components in the directions of the longitudinal, lateral and vertical axes of the vehicle

- angular rate sensors -DTS model ARS- $8 \mathrm{~K}^{\circledR}$, mounted in the centre of gravity of the vehicle, to measure the angular rate components around the longitudinal, lateral and vertical axes of the vehicle

- DTS recording system to record with sampling rates up to $100 \mathrm{kHz}$

- laser device to measure the impact velocity of the car (at a distance of $15 \mathrm{~m}$ from the barrier)

- 3 Phantom ${ }^{\circledR}$ cameras for fast photos.

The location of the centre of gravity of the test car was examined in the Laboratory of Testing Vehicles, Automotive Industry Institute, Warsaw, Poland, according to the relevant standard.

\section{Experimental verification of modelling and simulation of selected crash test}

The test sections of the SP-05/2 barrier had a length of $64.00 \mathrm{~m}$ as measured along the concave arc with a radius of $150 \mathrm{~m}$. The central part with a length of $40.00 \mathrm{~m}$ was composed of 10 segments of guide rail, with a $4.00 \mathrm{~m}$ effective length each, and Sigma- $100^{\circledR}$ posts interspaced $2.00 \mathrm{~m}$. Barrier ends with a length of $12.00 \mathrm{~m}$ each were mounted horizontally, i.e. the end segments of the guide rail were horizontal.

The impact angle, as measured between the longitudinal axis of the vehicle and the tangent to the arc of the guiderail at the intersection of the vehicle axis with this arc, was $20^{\circ}$, which corresponds to an angle of $23^{\circ}$ between the axis of the drive track and the tangent to the guide arc in the middle of the barrier test section. The distance of the arc of the mounting the posts from the edge of the concrete pavement was $0.30 \mathrm{~m}$. The theoretical point of impact, i.e. the intersection of the drive track axis with the guide face arc was located at a distance of $7.00 \mathrm{~m}$ from the barrier centre.

The experimental and simulation crash tests for barrier SP-05/2 mounted in a horizontal concave arc of a $\mathrm{R}=150 \mathrm{~m}$ radius were carried out at the impact velocity of vi=97.7 km/h, reduced by $12.3 \mathrm{~km} / \mathrm{h}$ compared to the standard speed of $110 \mathrm{~km} / \mathrm{h}$. The simulation included a time interval of $0-3$ seconds measured from the collision start time. 


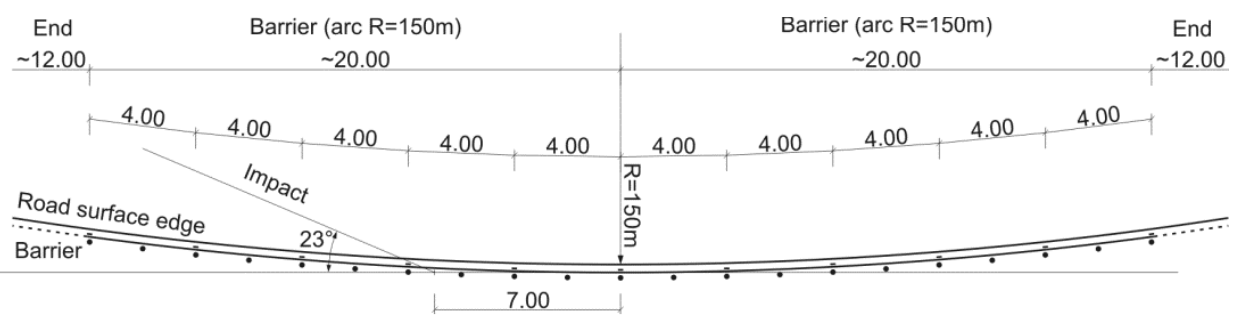

Fig. 1. Barrier SP-05/2 in horizontal concave arc of $\mathrm{R}=150 \mathrm{~m}$ radius and car impact location for TB32 test

Rys. 1. Bariera SP-05/2 w łuku poziomym wklęsłym o promieniu $\mathrm{R}=150 \mathrm{~m}$ I położenie uderzenia pojazdu dal testu TB32

Figure 2 compares the TB32 experimental and simulation tests, in the form of photos at selected time points, extracted from the video recorded from the top view. Figure 3 compares the relevant graphs of the acceleration severity index vs. time $t$. The experimental $\operatorname{ASI}(t)$ curve is shown in two variants:

(1) CAT: a curve determined at the sampling frequency of $105 \mathrm{~Hz}$, using DIAdem $2015^{\circledR}$ software -Crash Analysis Toolkit ${ }^{\circledR}$ module.

(2) LPP: a curve determined at the sampling frequency of $104 \mathrm{~Hz}$, according to the standard algorithm [1] programmed in the LS-PrePost postprocessor of the LS-Dyna FE code.

Table 1 compares the values of the functionality parameters of barrier SP-05/2 for the TB32 test. The measured/calculated and rounded (according to standard [2]) values are reported. The conclusions resulting from the full-scale experimental test TB32 and from comparison of the simulation and experimental test results are as follows:

(1) In the experimental crash test, the right front (RF) suspension and wheel were destroyed. After the first (major) impact of the car into the barrier, skidding (tail rotation) of the car and rebound of the car from the barrier, with significant crossing of the front line of the exit box were observed.

(2) The reason for the destruction of the RF suspension and wheel could be the age of the car (18 years) and the mileage $(\sim 200000 \mathrm{~km})$. In further tests, cars currently in use should be used.

(3) The experimental ASI $(t)$ plot maps the initial impact of the car into the guiderail and successive impacts into seven posts. The first six posts plasticized on contact with the ground, and were overturned on the roadside, after having broken the post-guide rail bolt connections.

(4) The compatibility of the experimental and simulation trajectories of the vehicle motion is good. Slight differences in the trajectories are only observed in the exit box. The main reason could be the lack of criteria for destruction of the RF suspension and wheel in the NCAC car numerical model. 


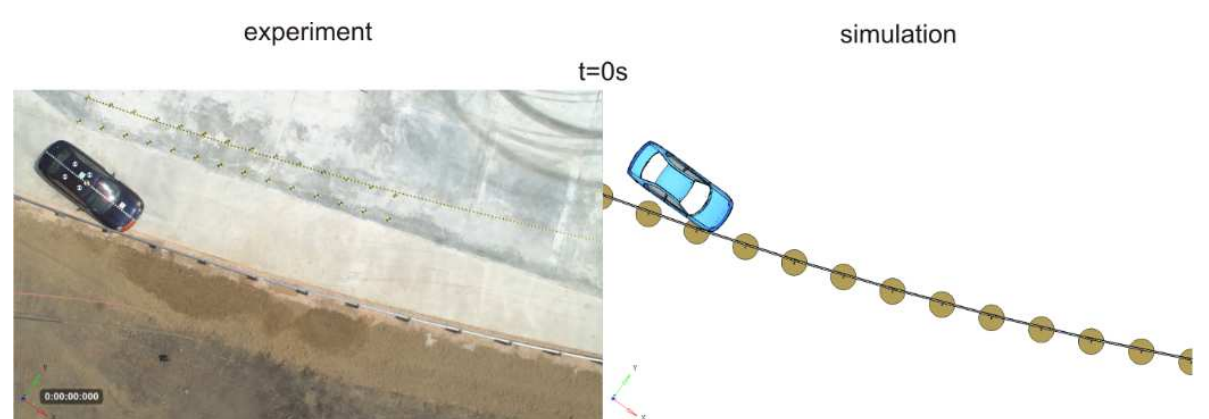

$\mathrm{t}=0.4 \mathrm{~s}$

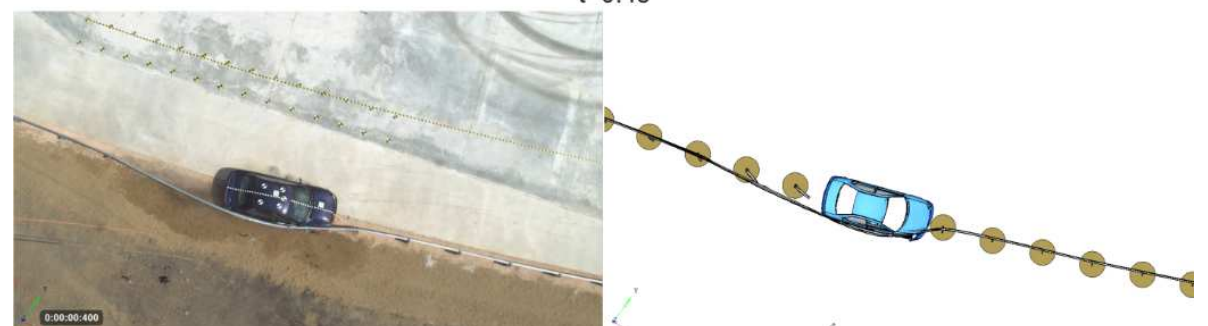

$\mathrm{t}=1.0 \mathrm{~s}$



$\mathrm{t}=2.0 \mathrm{~s}$

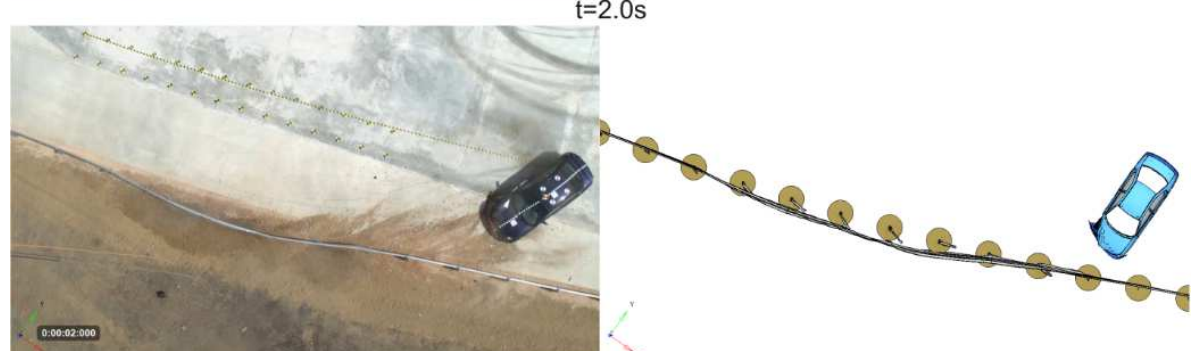

Fig. 2. Comparison of experimental and simulation tests TB32/CB, from top view, at selected time points

Rys. 2. Porównanie testu eksperymentalnego i symulacyjnego TB32, w widoku z góry, w wybranych punktach czasowych 


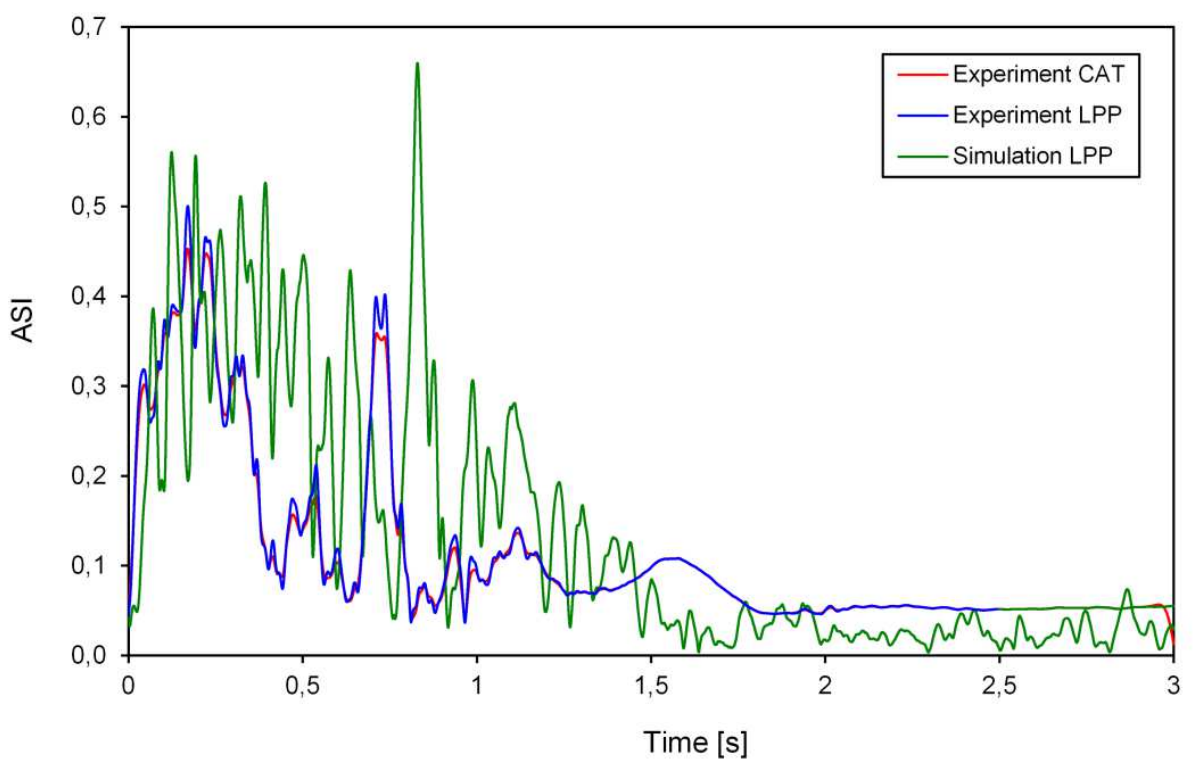

Fig. 3. Comparison of $\operatorname{ASI}(t)$ experimental and simulation graphs for test TB32

Rys. 3. Porównanie eksperymentalnego i symulacyjnego wykresu ASI $(t)$ dla testu TB32

Table 2. Summary of functionality parameter values of barrier SP-05/2 for test TB32

Tabela 2. Zestawienie wartości parametrów funkcjonalności bariery SP-05/2 dla testu TB32

\begin{tabular}{|c|c|c|c|}
\hline Conditions & ASI $[-]$ & THIV $[\mathrm{km} / \mathrm{h}]$ & W [m] \\
\hline Experiment, CAT & $0.45(0.5)$ & $26.26(26)$ & \multirow{2}{*}{$0.990(1.0)$} \\
\hline Experiment, LPP & $0.50(0.5)$ & $16.30(16)$ & \multirow{2}{*}{$1.076(1.1)$} \\
\hline Simulation, LPP & $\begin{array}{l}0.56(0.6 \text { for } t=\sim 0.2 \mathrm{~s}) \\
0.66(0.7 \text { for } t=\sim 0.9 \mathrm{~s})\end{array}$ & $16.49(16)$ & \\
\hline
\end{tabular}

(5) In the initial phase, the exact value of ASI in the simulation is higher by $12.0 \%$ than that in the experiment (LPP), which is assessed as good compatibility. Qualitative compatibility of the $\operatorname{ASI}(t)$ simulation and experimental graphs is acceptable. ASI in the simulation corresponds to the impact of the vehicle into the seventh post, causing the skidding and rebound of the car off the barrier. The main reason is the lack of criteria for the destruction of the RF suspension and wheel in the NCAC car model.

(6) The oscillations in the simulated $\operatorname{ASI}(t)$ graph prove too small vibration damping in the NCAC car numerical model. This model requires further modifications on damping and destruction criteria.

(7) The $\operatorname{ASI}(t)$ graphs calculated by the CAT and LPP algorithms vary slightly, which is caused by reducing the sampling rate by one rank in the LPP algorithm. 
(8) The simulated and experimental values of the THIV parameter are consistent. The simulated working width is higher by $8.7 \%$ than the width in the experiment, which is assessed as good compatibility.

(9) The criteria for approval for the TB32 crash test for a SP-05/2 barrier of class N2-W4-A, built on a horizontal concave arc of a radius of $\mathrm{R}=150 \mathrm{~m}$, are met except for the exit box criterion. This conclusion is valid for both the simulation and the experiment.

\section{Final conclusions}

(1) Protective road barriers of class N2-W4-A applied on road bends with a relatively small radius ( $150 \mathrm{~m}$ or so), the exit box criterion in the TB32 crash test may not be met, even at a reduced velocity of the car, by $10 \%$ compared to the standard velocity.

(2) In the experimental TB32 crash test for a road safety barrier of class N2-W4-A, used on a horizontal concave arc of a $150 \mathrm{~m}$ radius, the front right suspension and wheel of the car were destroyed. After the major impact of the car into the barrier, skidding and rebound of the vehicle off the barrier, with substantial crossing of the front line of the exit box were observed.

(3) The possible reason for destruction of the FR suspension and wheel of the Dodge Neon car used in the experiments could be the car's age (18 years) and mileage $(\sim 200000 \mathrm{~km})$. In further TB32 tests, cars of different makes currently in use, weighting $1500 \mathrm{~kg}$ should be applied.

(4) The experimental verification of the TB32 simulation crash test for the selected curved barrier, is reasonably positive. The main reason for some differences between the experiment and the simulation could be the lack of criteria for destruction of the RF suspension and wheel in the NCAC numerical car model. This model requires further modifications.

\section{Acknowledgements}

This work was supported by the National Centre for Research and Development, Poland, under Grant No. PBS1/B6/14/2012. This support is gratefully acknowledged.

\section{References}

[1] PN EN 1317-1:2010, Road restraint systems - Part 1: Terminology and general criteria for test methods (in Polish), 2010.

[2] PN EN 1317-2:2010, Road restraint systems - Part 2: Performance classes, impact test acceptance criteria and test methods for safety barriers including vehicle parapets (in Polish), 2010.

[3] PN-EN 1317-5+A2:2012. Road restraint systems - Part 5: Product requirements and evaluation of conformity for vehicle restraint systems (in Polish), 2012. 
[4] Nycz D.B., Modelling and numerical research of crash tests for barrier of N2-W4-A category on road bends (in Polish), Ph.D. thesis, Military Univ. Technol. Press, Warsaw, Poland, 2015.

[5] Klasztorny M., Nycz D.B., Szurgott P.: Modelling and Simulation of Crash Tests of N2-W4-A Category Safety Road Barrier in Horizontal Concave Arc, Int. Journal of Crashworthiness, vol. 21, no. 6, 2016, pp. 644-659.

[6] Manual for Assessing Safety Hardware. The American Association of State Highway and Transportation Officials, 2009, http://books.google.pl/books?id= LV0mSYE9SOC\&printsec=frontcover $\& \mathrm{hl}=$ pl\& source $=$ gbs_ge_summary_r\&cad $=0 \# \mathrm{v}=$ onepage $\&$ $\mathrm{q} \& \mathrm{f}=$ false, uploaded 2014-09-18.

[7] Vehicle models, National Crash Analysis Center, USA, http://www.ncac.gwu.edu/ $\mathrm{vml} /$ models.html, uploaded 2014-09-18.

[8] Hallquist J. O., LS-DYNA Keyword User's Manual, Livermore Software Technology Corp., Livermore, CA, USA, May 2007.

[9] System N2-W4-A (SP-05/2), Stalprodukt S.A., Bochnia, Poland, 2011.

\title{
WERYFIKACJA EKSPERYMENTALNA SYMULACJI TESTU ZDERZENIOWEGO TB32 DROGOWEJ BARIERY OCHRONNEJ SP-05/2 W LUKU POZIOMYM WKLĘSEYM
}

\begin{abstract}
Streszczenie
Przedmiotem badań numerycznych i eksperymentalnych jest stalowa taśmowa drogowa bariera ochronna, składająca się z prowadnicy typu B, słupków Sigma-100 w odstępach 2,00 m oraz elementów podporowych. Bariera jest w łuku poziomym wklęsłym o promieniu $150 \mathrm{~m}$. Test zderzeniowy TB32 według PN-EN 1317 przeprowadzono na poligonie Przemysłowego Instytutu Motoryzacji w Warszawie, z użyciem samochodu Dodge Neon. Zastosowano metodologię modelowania numerycznego i symulacji układu bariera - pojazd opracowaną przez część zespołu autorów. Symulację ww. testu zderzeniowego przeprowadzono przy zastosowaniu systemu LS-Dyna v.971, przy zachowaniu warunków testu eksperymentalnego. Analizą objęto wszystkie parametry funkcjonalności bariery określone w normie PN-EN 1317, m.in. ASI, THIV, szerokość pracująca, trajektoria ruchu pojazdu w polu wyjścia. Przeprowadzono weryfikację eksperymentalną modelowania numerycznego i symulacji testu TB32. Wynik weryfikacji oceniono pozytywnie. Udowodniono, zarówno numerycznie, jak i eksperymentalnie, że w rozpatrywanym przypadku bariery w łuku poziomym test TB32 nie spełnia kryterium pola wyjścia pojazdu.
\end{abstract}

Słowa kluczowe: drogowa bariera ochronna w łuku poziomym wklęłym, symulacyjny test zderzeniowy, eksperymentalny test zderzeniowy, weryfikacja eksperymentalna modelowania i symulacji

Przestano do redakcji: 17.02.2017 r.

Przyjęto do druku: 28.04.2017 r. 